\title{
The Effect of COVID-19 Pandemic on Health Anxiety, Death Anxiety and Somatic Symptoms in University Students
}

\section{COVID-19 Pandemisinin Üniversite Öğrencilerinde Sağlık Anksiyetesi, Ölüm Kaygısı ve Bedensel Belirtiler Üzerine Etkisi}

\author{
¿Lütfiye Söğütlü̈', @Seyyide Şifa Göktaş' \\ 1 University of Health Science, Faculty of Life Science, Department of Psychology Istanbul, Turkey
}

\begin{abstract}
Objective: Coronavirus disease 2019 (COVID-19), which was first identified in Wuhan, China's Hubei province in December 2019, and affected the whole world, although it may seem that it affects the elderly and its comorbid population more seriously, as the data on the disease increased, it was observed that the disease significantly affected young and non-comorbid people as well. The aim of this study is to examine the health anxiety, death anxiety and physical symptoms caused by the pandemic in university students who are interrupted with formal education and started to spend most of their days at their homes.
\end{abstract}

Material and Method: 789 students consisting of two year degree and undergraduate university students who have formal education in İstanbul province were included in the research. In the research, a data collection tool consisting of four parts, namely Sociodemographic Data Form, Health Anxiety Scale (HAS), Death Anxiety Scale (DAS) and DSM-5 Level 2 Somatic Symptoms Scale (SSS) were used.

Results: It was determined that as students' health anxiety levels were $31.9 \%$, death anxiety levels were $48.3 \%$, and physical symptom severity levels were $32.6 \%$. The fact that the person has a COVID-19 contact history and hospital application or hospitalization in near of kin and the test is positive, makes a significant impact in effect of health anxiety on death anxiety and physical symptom severity and the effect of death anxiety on bodily symptom severity.

Conclusion: When the psychiatric results of the pandemic were evaluated, it was found that the students had below the average health anxiety and physical symptom severity and moderate death anxiety. Therefore, this result shows that the young population also has serious mental uneasiness.

Keywords: COVID-19, pandemia, health anxiety, death anxiety, somatic symptoms.
Öz

Amaç: Illk kez Aralık 2019'da Çin'in Hubei eyaleti Wuhan'da tanımlanan ve tüm dünyayı etkisi altına alan Coronavirus hastalığı 2019 (COVID-19), ilk başlarda yaşlı ve komorbiditesi olan nüfusu daha ciddi şekilde etkiliyor gibi görünse de hastalıkla ilgili veriler arttıkça hastalığın gençleri ve komorbid hastalığı olmayanları da önemli derecede etkilediği gözlemlenmiştir. Bu çalışmada amaçlanan örgün eğitime ara verilen ve günlerinin büyük kısmını evlerinde geçirmeye başlayan üniversite öğrencilerinde pandeminin yol açtığı sağlık anksiyetesi, ölüm kaygısı ve bedensel belirtileri incelemektir.

Gereç ve Yöntem: Araştırmaya İstanbul ilinde örgün öğrenim gören ön lisans, lisans, birinci ve ikinci öğretim öğrencilerinden oluşan 789 öğrenci dahil edilmiştir. Araştırmada Sosyodemografik Veri Formu, Sağlık Anksiyetesi Ölçeği (SAÖ), Ölüm Kaygısı Ölçeği (ÖKÖ) ve DSM-5 Düzey 2 Bedensel Belirtiler Ölçeği (BBÖ) olmak üzere dört bölümden oluşan bir veri toplama aracı kullanılmıştır.

Bulgular: Öğrencilerin sağlık anksiyetesi düzeylerinin \%31,9; ölüm kaygısı düzeylerinin \%48,3 ve bedensel belirti şiddeti düzeylerinin \%32,6 olduğu saptanmıştır. Kişinin kendisinde COVID-19 temas öyküsü ve hastane başvurusu olması veya birinci derece yakınlarında hastane yatışı olması ve testin pozitif çıkması sağlık anksiyetesinin ölüm kaygısı ve bedensel belirti şiddeti üzerindeki etkisi ile ölüm kaygısının bedensel belirti şiddeti üzerindeki etkisini anlamlı hale dönüştürmektedir.

Sonuç: Pandeminin ruhsal sonuçları değerlendirildiğinde, öğrencilerin ortanın altında sağlık anksiyetesi ile bedensel belirti şiddetine ve orta düzeyde ölüm kaygısına sahip oldukları tespit edilmiştir. Dolayısıyla bu sonuç, genç nüfusun da ciddi şekilde ruhsal zorlanma yaşadığını göstermektedir.

Anahtar Kelimeler: COVID-19, pandemi, sağlık anksiyetesi, ölüm kaygısı, bedensel belirtiler.

Corresponding (illetişim): Lütfiye Söğütlü, University of Health Science, Faculty of Life Science, Department of Psychology. Selimiye Mah. Atölyeler Cad. No:4 34668 Üsküdar, Istanbul, Turkey

E-mail (E-posta): lutfiyeulgeli@hotmail.com

Received (Geliş Tarihi): 11.02.2021 Accepted (Kabul Tarihi): 11.03.2021 


\section{INTRODUCTION}

The new type of coronavirus disease (COVID-19) originated in Wuhan, China's Hubei Province, and spread rapidly throughout China and around the world. A cluster of pneumonia of unknown pathogen was identified after the appearance of the first cases and the agent of pneumonia was detected as a new coronovirus and was defined as severe acute respiratory syndrome coronavirus 2 (SARS-Cov-2). ${ }^{[1-3]}$

As a result of the genetic analysis of the virus, it was determined that the pathogen was closely associated with bat coronavirus known as BatCoV and RatG13 and that the source was bats. High probability of transmission from animal to human, then 15 health workers infected by an infected patient confirmed human to human transmission. ${ }^{[4]}$ As a result, COVID-19 has been declared by the Chinese Government and the World Health Organization (WHO) as an international public health state of emergency and pandemic that requires high-level protective and control measures.

First Covid-19 case was detected on March 11, 2020, in Turkey. According to the T.R. Ministry of Health data on May 7, 2020, the total number of 131.744 cases is 3.584 as the total number of deaths and as of 16 March 2020 formal education has been suspended. ${ }^{[5]}$ Due to reasons such as the rapid spread of pandemic across the continents, increased number of confirmed cases and deaths, changing the way people are used to live, interrupting formal education within the scope of protective measures, social isolation, continuous news about illness and death in social media; immense anxiety, stress, depression and psychological effects occur in the society. ${ }^{[6,7]}$

Pandemic can be a stressful situation for people. Fear and anxiety about the disease can become very intense and can lead to negative strong emotions in adults and children. Elderly people who are under the risk of serious effect by Covid-19 and have chronic disease, children and young people, doctors, other healthcare professionals, people with mental illness can react stress caused by pandemic more seriously. ${ }^{[8,9]}$

Health anxiety is a disorder that occurs with negative interpretation of the usual physical sensations in the person, even though there are no physical diseases. ${ }^{[10]}$ Health anxiety occurs in pandemics when physical sensations are interpreted as signs of disease, including related to infectious diseases such as fever, cough, muscle aches. Physical symptoms tend to be disastrous in those with severe health anxiety, by increasing the level of anxiety, symptoms become the focal point of the person and the person mentally goes around the circle. This situation can prevent a person from making sound judgement and developing appropriate healthy behaviors. ${ }^{[1]]}$ Many people think that they show signs of COVID-19 or have an infection during this period.

Every individual, regardless of age, has some kind of relationship with death. At the same time, the death perception of the individuals in this process also changes constantly. Death anxiety is a feeling that begins from birth and lasts a lifetime. There is no consensus on how age changes affect death anxiety. On the other hand, death is a fact that takes place outside of a person's own life. Therefore, people's attitudes towards death are changed by being influenced by their experiences of deaths of other people around them. When the literature is researched, there is a positive relationship between death anxiety and somatic symptoms in all studies. ${ }^{[12]}$ It is possible that increased anxiety level of death in the pandemic environment may exacerbate physical symptoms.

If we look at somatic symptoms, physical symptoms are the most common individual expressions of social problems and emotional distress all over the world and among different cultural groups. ${ }^{[13]}$ As well as these symptoms may be part of some unexplained syndromes such as chronic fatigue syndrome, irritable bowel syndrome, fibromyalgia, it can be aspects of anxiety and depression. Sometimes it seems as a symptom alone, without a defined organic diagnosis. ${ }^{[14]}$ It has been reported that comorbid psychiatric illness and coercive life events often lead to amplification of somatic symptoms. ${ }^{[15]}$ In the light of all this information, if we look at the pandemic environment; although this situation is a new mental state for the whole world, the psychological effects of the old disaster experiences are available in the literature. In disasters related to infectious diseases, due to the reasons such as disease is contagious, stigmatization, primary physical effects of the disease, continuing the disease in a certain period of time, fear of transmitting the disease to others, unclear treatment and prognosis, sudden changes in life conditions, in whole society, especially people who are primary affected, increased levels of depression, post-traumatic stress disorder and anxiety are reported. ${ }^{[16]}$

The aim of this study is to investigate the effect of COVID-19 in university students' health anxiety, death anxiety and somatic symptoms. In addition, it is aimed to examine Covid-19 effect of health anxiety on death anxiety and somatic symptoms, and death anxiety on somatic symptom in university students. It is thought that the young population and the university students, who are a serious part of this young population, may be significantly affected psychologically. Especially in the literature, it was researched the effect of pandemia in university students' on depression, anxiety and post-traumatic stress disorder, but it could not be found any research article about health anxiety and fear of death and their effects on somatic symptoms.

\section{MATERIAL AND METHOD}

\section{Sample}

The universe of the research consists of two year degree and undergraduate students who receive formal education in the city of Istanbul where the COVID-19 pandemic affects most. According to the information management system data of the higher education institution, there are approximately 1.5 
million university students in İstanbul province meeting those conditions. Considering the reliability with the sample error of 0.05 , the universe, the number of sub-participation was determined as 384 , and 789 university students were included in the study. ${ }^{[17]}$ Socio-demographic data form and scales containing questionnaire form were prepared by Google Drive program and applied to participants by sharing it via social media groups and e-mail.

\section{Data Collection Tool}

Online survey method was used by using Google Drive program to collect the research data. In the survey; totally 4 sections ranked as sociodemographic form, Health Anxiety Scale (HAS), Death Anxiety Scale (DAS), and DSM-5 Level 2 Somatic Symptom Scale (SSS).

Sociodemographic Data Form: Questions about sociodemographic characteristics such as age and gender etc. of the participants and Covid-19 were prepared and posed by the researcher.

Health Anxiety Scale (HAS): The scale developed by Salkovskis et al. ${ }^{[18]}$ is a self-report scale consisting of 18 items. Turkish validity and reliability study was done by Aydemir et al. ${ }^{[19]}$ The 14 items of the scale consist of expressions containing four-line answers that question the mental state of the patients. In the remaining 4 questions, the patients are asked to put forward an idea about how their mental state might be with the assumption of a serious illness they have and questioning accordingly. Scoring of the scale is between 0-3 for each item, and a high score indicates a high level of health anxiety.

Death Anxiety Scale (DAS): The scale developed by Templer has been applied in men and women groups, in different age groups, patients and control groups and in different occupational groups. ${ }^{[20]}$ Adapted to Turkish by Akça et al. ${ }^{[21]}$ It is a self-report scale consisting of 15 items. As the total score obtained from the scale answered as yes ( 1 point $)$ and no $(0$ points) increases, death anxiety increases.

DSM-V Level 2 Somatic Symptoms Scala (SSS): The reliability and validity study of the somatic symptoms scala prepared for DSM-5 was performed by Sarıkavak et al. ${ }^{[22,23]}$ SSS is an adaptation of 15-item Patient Health Questionnaire Physical Symptoms Scale (PHQ-15). The scale provides a triple likert-type assessment that scans physical symptoms $(0=$ not disturbed at all, $1=$ =slightly disturbed, $2=$ =very disturbed). High score indicates that the severity of the somatic symptoms is higher.

\section{Process}

Ethics committee approval for the study, numbered 46418926-050.03.04, dated 24.04.2020, was received from Hamidiye Scientific Research Ethics Committee of Health Sciences University. A questionnaire application including sociodemographic data form and scales was applied to university students between 25-29 April 2020.

\section{Data Analysis}

In the analysis of the data, quantitative analysis method was employed and descriptive statistical methods such as mean, standard deviation, percentage, skewness and kurtosis and simple linear regression analysis were used. For this purpose, SPSS 24.0 program was used. Significance level was accepted as $\mathrm{p}<0.05$ and confidence interval as $95 \%$. In addition, it is determined whether the data show normal distribution or not, by the skewness and kurtosis coefficients were examined in line with the recommendations of Tabachnick and Fidell. ${ }^{[24]}$ Because the skewness and kurtosis values in the range of \pm 1.50 are interpreted as the normal distribution. The distortion and kurtosis coefficients of the death anxiety total score included in the regression in the research were determined as 0.349 and 1.402; skewness and kurtosis coefficients of the total score of health anxiety are 0.732 and 1.031 , and skewness and kurtosis coefficients of the total score of somatic symptom severity are 0.392 and -0.337 .

\section{RESULTS}

This research was carried out in April 2020 to evaluate the relationships between students' health anxiety, death anxiety, and somatic symptom level with the COVID-19 pandemia. A total of 789 students, of which approximately three quarters were women and the average age was 21 , participated in the study. $2.2 \%$ of the participants have Covid- 19 contact history, $1.4 \%$ of them have hospital applications. The test result was determined positively in 5 students (6.3 per thousand of the participants) who applied to the hospital, and 1 of them was hospitalized. Moreover, the proportion of those who have contact history in their near of kin is $4.3 \%$; the rate of those with a positive result is $3.2 \%$ and the rate of hospitalized people is $2.6 \%$.

The sociodemographic characteristics and distribution of the participants according to the findings of COVID-19 are given in Table 1.

\begin{tabular}{llcc}
$\begin{array}{l}\text { Table 1. Sociodemographic Characteristics of the Participants and } \\
\text { COVID-19 Results }\end{array}$ & $\mathbf{n}$ & $\%$ \\
\hline & & 597 & 75.7 \\
\hline Gender & Memale & 192 & 24.3 \\
& Min.-Max. & $18-26$ \\
Age & Mean-SD & $21.51 \pm 3.97$ \\
$\begin{array}{l}\text { Do you have a COVID-19 contact } \\
\text { history? }\end{array}$ & Yes & 17 & 2.2 \\
$\begin{array}{l}\text { If the COVID-19 test was done, what is } \\
\text { your test result? }\end{array}$ & Positive & 5 & 11 \\
$\begin{array}{l}\text { Do you have any COVID-19 contact } \\
\text { history from your near of kin? }\end{array}$ & No & 10 & $95.5^{*}$ \\
$\begin{array}{l}\text { If your near of kins were tested, is there } \\
\text { any positive COVID-19 test result? }\end{array}$ & Yes & 34 & 4.3 \\
$\begin{array}{l}\text { Is there any hospitalization due to } \\
\text { COVID-19 among your near of kin? }\end{array}$ & Yes & 21 & 3.2 \\
$\begin{array}{l}\text { Total } \\
\text { * The rate among those who applied for a hospital due to CovID-19 is given. Min: Minimum, Max: } \\
\text { Maximum, SD: Standart Deviation }\end{array}$ & & 20 & 2.6 \\
\hline
\end{tabular}


The mean of the health anxiety of the students included in the research determined as $17.25 \pm 7.08$; the average of death anxiety was $7.25 \pm 2.06$ and the average of somatic symptom severity was $9.78 \pm 5.52$. When calculated to the lowest and highest scores that can be obtained from the relevant scales, it is possible to say that students' health anxiety levels are $31.9 \%$; death anxiety levels are $48.3 \%$ and somatic symptom severity levels are $32.6 \%$

Descriptive statistics on the health anxiety, death anxiety and somatic symptom severity levels of the students included in the study are given in Table $\mathbf{2}$.

Table 2. Descriptive Statistics on Health Anxiety, Death Anxiety and Somatic Symptom Severity of the Participants

\begin{tabular}{lccccc} 
& Min. & Max. & Mean & SD & \%* \\
\hline Health Anxiety & 0.00 & 50.00 & 17.25 & 7.08 & 31.9 \\
Death Anxiety & 0.00 & 15.00 & 7.25 & 2.06 & 48.3 \\
Somatic Symptom Severity & 0.00 & 27.00 & 9.78 & 5.52 & 32.6 \\
\hline $\begin{array}{l}\text { * Rated to the lowest and highest scores that can be obtained from the scales. } \\
\text { Min: Minimum, Max: Maximum, SD: Standart Deviation }\end{array}$ \\
\hline
\end{tabular}

It was found that health anxiety significantly increased death anxiety in students with COVID-19 contact history and hospital application and positive test results, hospitalization in near of kin and those close relatives' positive test results $(p<0.05)$. If the person has a COVID-19 contact history and hospital application, or hospitalization in near of kin and the close relatives' test is positive, the effect of health anxiety on death anxiety becomes significant. According to this; COVID-19 makes the impact of health anxiety on death anxiety significant.
The findings obtained as a result of simple linear regression analysis to determine whether COVID-19 significantly differentiates the effect of health anxiety on death anxiety are given in Table 3.

It was found that health anxiety significantly increased the severity of somatic symptoms in students with COVID-19 contact history and hospital application and positive test results, hospitalization of near of kin and those close relatives' positive test results $(p<0.05)$. If the person has a COVID-19 contact history and hospital application or hospitalization in near of kind and the close relatives' test is positive, the effect of health anxiety on the severity of somatic symptoms makes it significant. Accordingly, COVID-19 turns the effect of health anxiety on somatic symptom severity into a significant way.

In Table 4, the findings obtained as a result of simple linear regression analysis to determine whether COVID-19 significantly differentiates the effect of health anxiety on somatic symptom severity is given.

It was found that death anxiety significantly increased the severity of somatic symptom in students with COVID-19 contact history and hospital application and positive test results, hospitalization in near of kind and the close relatives' positive test results $(p<0.05)$. If the person has a COVID-19 contact history and hospital application or hospitalization in near of kind and the close relatives' test is positive, the effect of death anxiety on the severity of somatic symptoms makes it signifacant. Accordingly, COVID-19 makes the effect of death anxiety on somatic symptom severity significant.

Table 3. The Effect of Health Anxiety on Death Anxiety

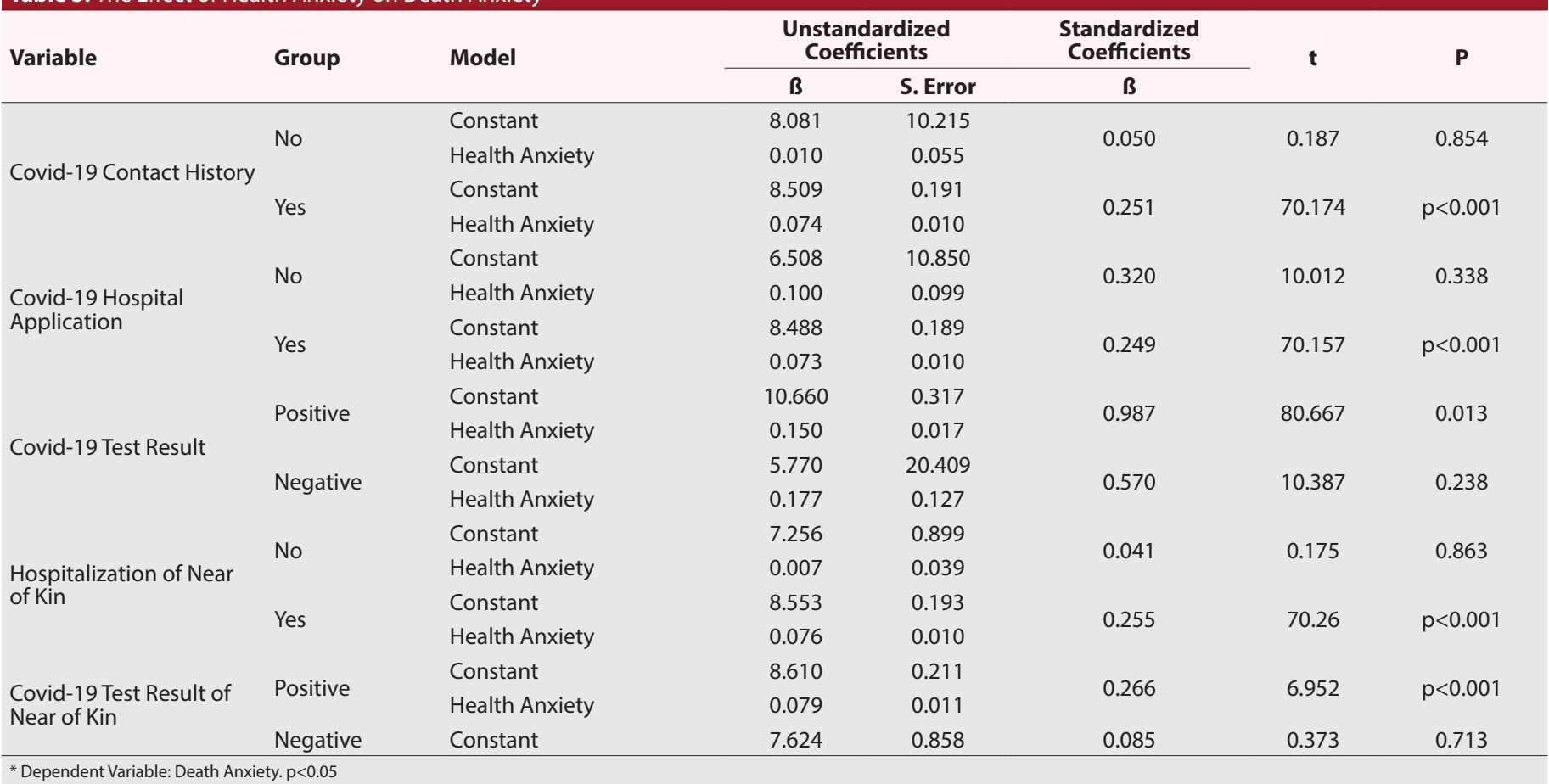


In Table 5, the findings obtained as a result of simple linear regression analysis to determine whether COVID-19 significantly differentiates the effect of death anxiety on bodily symptom severity are given.

\begin{tabular}{|c|c|c|c|c|c|c|c|}
\hline \multirow{2}{*}{ Variable } & \multirow{2}{*}{ Group } & \multirow{2}{*}{ Model } & \multicolumn{2}{|c|}{$\begin{array}{l}\text { Unstandardized } \\
\text { Coefficients }\end{array}$} & \multirow{2}{*}{$\begin{array}{c}\text { Standardized } \\
\text { Coefficients } \\
\text { B } \\
\end{array}$} & \multirow[t]{2}{*}{$\mathbf{t}$} & \multirow[t]{2}{*}{$\mathbf{P}$} \\
\hline & & & B & S. Error & & & \\
\hline \multirow{2}{*}{ Covid-19 Contact History } & No & Health Anxiety & 0.145 & 0.129 & 0.287 & 1.122 & 0.281 \\
\hline & Yes & Constant & 6.132 & 0.509 & 0.267 & 7.661 & $\mathrm{p}<0.001$ \\
\hline \multirow{3}{*}{$\begin{array}{l}\text { Covid-19 Hospital } \\
\text { Application }\end{array}$} & No & Health Anxiety & 0.573 & 0.188 & 0.712 & 3.046 & 0.467 \\
\hline & \multirow{2}{*}{ Yes } & Constant & 6.235 & 0.504 & \multirow{2}{*}{0.264} & \multirow{2}{*}{7.592} & \multirow{2}{*}{0.014} \\
\hline & & Health Anxiety & 0.205 & 0.027 & & & \\
\hline Covid-19 Test Result & Positive & Constant & 6.839 & 90.640 & 0.477 & 0.768 & 0.001 \\
\hline \multirow{3}{*}{$\begin{array}{l}\text { Hospitalization of Near } \\
\text { of Kin }\end{array}$} & & Health Anxiety & 0.175 & 0.121 & 0.323 & 1.440 & 0.105 \\
\hline & Yes & Constant & 6.041 & 0.508 & (273 & 7813 & $n<0001$ \\
\hline & res & Health Anxiety & 0.214 & 0.027 & 0.275 & 1.015 & $p<0.001$ \\
\hline & Positive & Constant & 8.596 & 20.705 & 0.235 & 1054 & $0<0001$ \\
\hline $\begin{array}{l}\text { Covid-19 lest Result of } \\
\text { Near of Kin }\end{array}$ & f vorive & Health Anxiety & 0.126 & 0.120 & (3) & דנטו 1 & p \\
\hline & Negative & Constant & 6.198 & 0.544 & 0.274 & 7.188 & 0.305 \\
\hline
\end{tabular}

Table 5. The Effect of Death Anxiety on Somatic Symptom Severity

\begin{tabular}{|c|c|c|c|c|c|c|c|}
\hline \multirow[t]{2}{*}{ Variable } & \multirow[t]{2}{*}{ Group } & \multirow[t]{2}{*}{ Model } & \multicolumn{2}{|c|}{$\begin{array}{l}\text { Unstandardized } \\
\text { Coefficients }\end{array}$} & \multirow{2}{*}{$\begin{array}{c}\text { Standardized } \\
\text { Coefficients } \\
\text { B }\end{array}$} & \multirow[t]{2}{*}{$\mathbf{t}$} & \multirow[t]{2}{*}{$\mathbf{P}$} \\
\hline & & & B & S. Error & & & \\
\hline \multirow{4}{*}{$\begin{array}{l}\text { Covid-19 Contact } \\
\text { History }\end{array}$} & \multirow{2}{*}{ No } & Constant & 10.762 & 5.349 & \multirow{2}{*}{0.051} & \multirow{2}{*}{0.190} & \multirow{2}{*}{0.852} \\
\hline & & Death Anxiety & 0.126 & 0.660 & & & \\
\hline & \multirow{2}{*}{ Yes } & Constant & 13.037 & 0.716 & \multirow{2}{*}{0.170} & \multirow{2}{*}{4.786} & \multirow{2}{*}{$p<0.001$} \\
\hline & & Death Anxiety & 0.455 & 0.095 & & & \\
\hline \multirow{4}{*}{$\begin{array}{l}\text { Covid-19 Hospital } \\
\text { Application }\end{array}$} & \multirow{2}{*}{ No } & Constant & 3.073 & 6.832 & \multirow{2}{*}{0.347} & \multirow{2}{*}{1.110} & \multirow{2}{*}{0.296} \\
\hline & & Death Anxiety & 0.892 & 0.804 & & & \\
\hline & \multirow{2}{*}{ Yes } & Constant & 13.095 & 0.714 & \multirow{2}{*}{0.171} & \multirow{2}{*}{4.836} & \multirow{2}{*}{$p<0.001$} \\
\hline & & Death Anxiety & 0.459 & 0.095 & & & \\
\hline \multirow{4}{*}{ Covid-19 Test Result } & \multirow{2}{*}{ Positive } & Constant & 30.000 & 29.508 & \multirow{2}{*}{0.359} & \multirow{2}{*}{0.544} & \multirow{2}{*}{0.024} \\
\hline & & Death Anxiety & 2.000 & 3.674 & & & \\
\hline & \multirow{2}{*}{ Negative } & Constant & 4.010 & 6.749 & \multirow{2}{*}{0.692} & \multirow{2}{*}{1.917} & \multirow{2}{*}{0.128} \\
\hline & & Death Anxiety & 1.416 & 0.739 & & & \\
\hline \multirow{4}{*}{$\begin{array}{l}\text { Hospitalization of Near } \\
\text { of Kin }\end{array}$} & $\mathrm{Ne}$ & Constant & 10.762 & 5.869 & 0009 & 0037 & 0971 \\
\hline & & Death Anxiety & 0.029 & 0.776 & 0.009 & 1 & 0.911 \\
\hline & Yes & Constant & 12.797 & 0.716 & 0160 & 4474 & $n<0 \Omega 01$ \\
\hline & 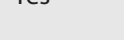 & Death Anxiety & 0.425 & 0.095 & 0.100 & & plo. \\
\hline & Pecitive & Constant & 5.305 & 5.384 & 0248 & 1118 & ( \\
\hline $\begin{array}{l}\text { Covid-19 Test Result of } \\
\text { Near of Kin }\end{array}$ & positive & Death Anxiety & 0.803 & 0.718 & 0.240 & 1.110 & 0.001 \\
\hline & Negative & Constant & 12.370 & 0.768 & 0.137 & 3.479 & 0.278 \\
\hline
\end{tabular}




\section{DISCUSSION}

With theglobal rapid spread ofCOVID-19 disease, psychological problems accompanying the pandemic also rapidly increased the public health burden. ${ }^{[25]}$ Publications examining the effects of COVID-19 on mental health report a severe increase in depression and anxiety levels in the general population due to uncertainty and health-related fears. ${ }^{[26]}$ However, in order to better understand the psychological effects of the pandemia, more detailed studies with special groups are needed beyond the general population. The aim of this study is to focus on the mental problems of university students who constitute an important part of the young population of the society. Such studies are needed for mental rehabilitation studies during and after a pandemia.

Psychological distress levels are reported to be high in university students as part of their development period. It is known that one of the five university students before pandemic experienced have had one or more diagnosable mental disorders, and the psychological effects of COVID-19 increased this number, making the mental health problems of university students worse. ${ }^{[27,28]}$ UNESCO estimates that the closure of educational institutions due to the pandemia that affects half the students in the world which corresponds to approximately 890 million students in 114 countries. ${ }^{[29]}$ Due to academic troubles, because of students' motivation decrease and pressure to learn on their own increase, as a result of their routine lives change reluctance for education and education dropout rates increase. ${ }^{[30]}$ Suspending formal education and moving into online education within the scope of combating COVID-19 increases academic stress level for students, however, when combined with stress due to the direct effect of the disease, it creates a serious mental health burden for students. Although old age seems to increase the risk of infection and mortality associated with COVID-19, anxiety level is significantly higher in the 21-40 age group in an online study of 10,754 people and covering the entire population. Also, in this study, anxiety level was found significantly higher in those who have at least one family member, relative or friend infected with COVID- 19 . ${ }^{[31]}$ In our study, it is seen that while university students' health anxiety, death anxiety and somatic symptoms have increased, health anxiety significantly increases death anxiety and somatic symptoms in those with a history of COVID-19 contact, hospital application due to COVID-19 and positive test results, hospitalization of near of kind and the close relatives' positive test results. Also in the same group, death anxiety significantly increases the somatic symptoms.

In a study with university students; it was found that $0.9 \%$ of the participants experienced severe anxiety, $2.7 \%$ had moderate anxiety and $21.3 \%$ had mild anxiety. A positive correlation was found between having relatives or acquaintances infected with COVID-19 and anxiety levels of university students. ${ }^{[32]}$ This finding is compatible with our study.
In a study of 1210 people in the general population in China, $53.8 \%$ of the participants rated the psychological impact of the epidemic as moderate or severe; $16.5 \%$ reported moderate to severe depressive symptoms, $28.8 \%$ moderate to severe anxiety symptoms, and $8.1 \%$ reported moderate to severe stress level. It is reported that there is a relationship between being a woman in terms of gender and a student, having specific physical symptoms (for example, muscle pain, dizziness) and the individual's poor medical condition, and high stress, anxiety and depression levels. ${ }^{[26]}$ In a study conducted with 8079 adolescents during pandemia, respectively, the frequency of depressive symptoms, anxiety symptoms, and depressive and anxiety symptoms were found to be $43.7 \%, 37.4 \%$ and $31.3 \%$, and the prevalence of depressive and anxiety symptoms increased with age. Furthermore, a negative correlation has been reported between COVID-19 awareness level and mental response in adolescents. ${ }^{[33]}$ These studies, on the other hand, show the mental influences among university students and reveal the necessity of further studies to be done with this group.

The limitation of our study is that the scales are filled online and that the interviews could not be made face to face due to the pandemic situation. Longitudinal studies on the subject will give better results.

\section{CONCLUSION}

As a result, in order to better understand the psychological effects of the pandemia, studies conducted in different groups containing different aspects of effects are needed. As we have seen in the literature, studies examining the pandemic's psychological effects on university students are limited. We think that our study will contribute to the literature and psychological rehabilitation studies during and after the pandemia.

\section{ETHICAL DECLARATIONS}

Ethics Committee Approval: Ethics committee approval for the study, numbered 46418926-050.03.04, dated 24.04.2020, was received from Hamidiye Scientific Research Ethics Committee of Health Sciences University.

Informed Consent: Informed consents were obtained from all patients.

Referee Evaluation Process: Externally peer-reviewed.

Conflict of Interest Statement: The authors have no conflicts of interest to declare. Financial Disclosure: The authors declared that this study has received no financial support.

Author Contributions: LS: Conception or design of the work, data collection, data analysis, results, discussion and literature review. SŞG: Data collection and literature review, translate. 


\section{REFERENCES}

1. Lu H, Stratton CW, Tang YW:Outbreak of pneumonia of unknown etiology in Wuhan, China: The mystery and the miracle. J Med Virol 2020;92(4):4002.

2. Zhu N, Zhang D, Wang W, et al. China Novel Coronavirus Investigating and Research Team. A Novel Coronavirus from Patients with Pneumonia in China, 2019. N Engl J Med 2020;20:382(8):727-33.

3. Zhou P, Yang XL, Wang XG, et al. A pneumonia outbreak associated with a new coronavirus of probable bat origin. Nature 2020;579:270-273.

4. Li Q, Guan X, Wu P, et al. Early transmission dynamics in Wuhan, China, of novel coronavirus-infected pneumonia. N Engl J Med 2020;382:1199207.

5. TC. Sağlık Bakanlığı. COVID-19 Bilgilendirme Platformu. 2021. https:// covid19.saglik.gov.tr/

6. Xiang YT, Yang Y, Li W, et al. Timely mental health care for the 2019 novel coronavirus outbreak is urgently needed. Lancet Psychiatry 2020;7(3):2289.

7. Kang L, Li Y, Hu S, et al. The mental health of medical workers in Wuhan, China dealing with the 2019 novel coronavirus. Lancet Psychiatry. 2020;7(3):e14.

8. Centers for Disease Control and Prevention, CDC (http://www.cdc.gov/ coronavirus/2019-ncov/about/coping.html)

9. Söğütlü Y, Söğütlü L, Göktaş S. Relationship of COVID-19 Pandemic with Anxiety, Anger, Sleep and Emotion Regulation in Healthcare Professionals. J Contemp Med. 2021;11(1):41-9.

10. Abramowitz JS, Olatunji BO, Deacon BJ. Health anxiety, hypochondriasis, and the anxiety disorders. Behav Ther 2007;38:86-94.

11. Asmundson GJG, Taylor S. How health anxiety influences responses to viral outbreaks like COVID-19:What all decision-makers, health authorities, and health care professionals need to know. J Anxiety Disord 2020;71:102-211.

12. Aan de Stegge BM, Tak LM, Rosmalen JGM, Oude Voshaar RC. Death anxiety and its association with hypochondriasis and medically unexplained symptoms:A systematic review. J Psychosom Res 2018;115:58-65.

13. Kirmayer LJ, Young A. Culture and somatization:clinical, epidemiological and ethnographic perspectives. Psychosom Med 1998;60:420-30.

14. Nimnuan C, Hotopf M, Wessely S. Medically unexplained symptoms:an epidemiological study in seven specialities. J Psychosom Res 2001;51:3617.

15. Katon W, Sullivan M, Walker E. Medical symptoms without identified pathology:Relationship to psychiatric disorders, childhood and adult trauma, and personality traits. Ann Intern Med 2001;134:917-925

16. Mak IW, Chu CM, Pan PC, Yiu MG, Chan VL. Long-term psychiatric morbidities among SARS survivors. Gen Hosp Psychiatry 2009;31(4):31826.

17. Yazıcıoğlu Y, Erdoğan S. Spss uygulamalı bilimsel araştırma yöntemleri. Ankara:Detay Yayıncılık, 2004.

18. Salkovskis PM, Rimes KA, Warwick HM, Clark DM. The Health Anxiety Inventory:development and validation of scales for the measurement of health anxiety and hypochondriasis. Psychol Med 2002;32:843-53.

19. Aydemir Ö, Kirpinar I, Sati T, Uykur B, Cengisiz C. Reliability and Validity of the Turkish Version of the Health Anxiety Inventory. Noro Psikiyatr Ars 2013;50(4):325-31.

20. Templer DI. The construction and validation of death anxiety scale. J General Psychol 1970;82,165-74.

21. Akça F, \& Köse İA. Ölüm Kaygısı Ölçeğinin Uyarlanması:Geçerlik ve Güvenirlik Çalışması. Klinik Psikiyatri Derg 2008; 11(1).

22. American Psychiatric Association. Online Assessment Measures. (Erişim tarihi:18.01.2017), http://www.psychiatry.org/psychiatrists/practice/ds m/educational-resources/assessment-measures.

23. Sarıkavak T, Balıkçı K, Aydemir Ö. Reliability and validity of Turkish Form of Somatic Symptom Scale and Level 2 Somatic Symptom Scale. Anatolian J Psychiatry 2017; 18:63-67.
24. Tabachnick BG, Fidell LS. Using Multivariate Statistics (6th ed.). Boston:Allyn \& Bacon, 2013.

25. Torales J, O'Higgins M, Castaldelli-Maia JM, Ventriglio A:The outbreak of COVID-19 coronavirus and its impact on global mental health. Int J Soc Psychiatry 2020;66 (4):317-20.

26. Wang C, Pan R, Wan X, et al. Immediate Psychological Responses and Associated Factors during the Initial Stage of the 2019 Coronavirus Disease (COVID-19) Epidemic among the General Population in China. Int J Environ Res Public Health 2020;6;17(5).

27. Auerbach RP, Alonso J, Axinn WG, et al. Mental disorders among college students in the World Health Organization World Mental Health Surveys Psychol Med 2016;3:1.

28. American College Health Association. (2019). American College Health Association:National College health assessment II:Reference group executive summary spring 2019. American College Health Association. https://doi.org/10.1080/24745332.2019.1620558

29. UNESCO, 2020. COVID-19 educational disruption and response. https:// en.unesco.org/themes/education-emergencies/coronavirus-schoolclosures.

30. Wickens CM. The academic and psychosocial impact of labor unions and strikes on university campuses. In Poulsen, M. E. (Ed.), Higher education:Teaching, internationalization and student issues (pp. 107133). Nova Scotia Publishers, 2011.

31. Moghanibashi-Mansourieh A. Assessing the anxiety level of Iranian general population during COVID-19 outbreak. Asian J Psychiatry 2020;51:102076.

32. Cao W, Fang Z, Hou G, et al. The psychological impact of the COVID-19 epidemic on college students in China. Psychiatry Res 2020;287:112934.

33. Zhou SJ, Zhang LG, Wang LL, et al. Prevalence and socio-demographic correlates of psychological health problems in Chinese adolescents during the outbreak of COVID-19. Eur Child Adolesc Psychiatry 2020; 29:749-58. 